\title{
INSTRUMENT OF CREATIVE THINKING SKILLS IN PROJECT BASED LEARNING PHYSICS
}

\author{
Aldi Setia Utama ${ }^{1^{*}}$, Undang Rosidin ${ }^{2}$, Agus Suyatna ${ }^{3}$ \\ ${ }^{1,2,3}$ Department of Physics Education, Postgraduate Program, Universitas Lampung, Indonesia
}

*Corresponding author: aldisetiautama004@gmail.com

\begin{tabular}{|c|c|}
\hline Article Info & "ABSTRACT \\
\hline Article history: & \multirow{8}{*}{$\begin{array}{l}\text { To identify students' creative thinking skills, appropriate } \\
\text { instrument is needed. This study aimed to produce a valid creative } \\
\text { thinking skills instrument. From several relevant studies, they only } \\
\text { focus their research on developing skills instruments using a } 4-D \\
\text { model approach and problem solving, while this research uses a } \\
\text { project-based pursuit approach. The results of the validation of the } \\
\text { three validators covering aspects of construction, substance, and } \\
\text { language, revealed that the average score of the validation results } \\
\text { for the construction aspects was } 83 \% \text { which was considered very } \\
\text { valid. The average score of the validation results on the substance } \\
\text { aspect is } 86 \% \text { with very valid criteria, and in the language aspect i } \\
\text { reaches } 85 \% \text { with very valid criteria. Accordingly, this instrumen } \\
\text { of creative thinking skills is said to have been qualified with very } \\
\text { decent and excellent quality for use in learning in schools to help } \\
\text { teachers to assess students' creative thinking skills. }\end{array}$} \\
\hline Received: March 17, 2021 & \\
\hline : March 27, 2021 & \\
\hline Published: March 31, 2021 & \\
\hline Keywords: & \\
\hline Assesment instruments & \\
\hline Creative thinking Skills & \\
\hline Project based learning physics & \\
\hline
\end{tabular}

\begin{tabular}{|c|c|}
\hline \multicolumn{2}{|c|}{$\begin{array}{l}\text { INSTRUMEN PENILAIAN KETERAMPILAN BERPIKIR } \\
\text { KREATIF PADA PEMBELAJARAN FISIKA BERBASIS PROYEK } \\
\text { ABSTRAK }\end{array}$} \\
\hline & ABSTRAK \\
\hline $\begin{array}{l}\text { Kata Kunci: } \\
\text { Instrumen penilaian } \\
\text { Keterampilan berpikir kreatif } \\
\text { Pembelajaran fisika berbasis } \\
\text { proyek }\end{array}$ & $\begin{array}{l}\text { Untuk mengidetifikasi keterampilan berpikir kreatif siswa, harus } \\
\text { menggunakan instrumen penilaian yang tepat. Penelitian ini } \\
\text { bertujuan untuk menghasilkan produk instrumen penilaian } \\
\text { keterampilan berpikir kreatif siswa yang valid. Dari beberapa } \\
\text { penelitian yang relevan memfokuskan penelitiannya pada } \\
\text { pengembangan instrumen penilaian keterampilan menggunakan } \\
\text { pendekatan model 4-D dan problem solving, sedangkan penelitian } \\
\text { ini menggunakan pendekatan pembejaran berbasis proyek. Hasil } \\
\text { penilaian dari ketiga validator yang mencakupi aspek kontruksi, } \\
\text { substansi, dan bahasa, mengungkapkan bahwa skor rata-rata hasil } \\
\text { validasi aspek konstruksi adalah 83\% yang termasuk kriteria sangat } \\
\text { valid. Skor rata-rata hasil validasi pada aspek substansi adalah } 86 \% \\
\text { yang termasuk kriteria sangat valid sedangkan untuk aspek } \\
\text { bahasa/budaya adalah 85\% yang termasuk kriteria sangat valid. } \\
\text { Insturmen penilaian keterampilan berpikir kreatif memenuhi syarat } \\
\text { dengan kualitas sangat layak dan sangat baik untuk diuji coba } \\
\text { disekolah untuk membantu para guru-guru untuk menilai } \\
\text { keterampilan berpikir kratif siswa. }\end{array}$ \\
\hline
\end{tabular}




\section{INTRODUCTION}

Assessment is an important and inseparable part of learning. One indicator of improving the quality of education can be seen through the student learning assessment score. Of course, this requires a good and unusual scoring system. A good assessment system will be able to provide an overview of the quality of learning so that it can help teachers plan a learning strategy. For students themselves, a good assessment system will be able to provide motivation to constantly improve their abilities [1]. Assessment must be carried out continuously and thoroughly. As stated in Permendikbud number 104 of 2014 concerning the assessment of learning outcomes, assessment of student learning outcomes includes competence in spiritual attitudes and social attitudes, knowledge competencies, and skills competencies which are carried out in a planned and systematic, during and after the learning process. [2].

In a learning, assessment is one of the most important stages [3]. Assessment needs to be done to find out how the results of a learning process are [4]. Educational assessment is the process of collecting and processing information to measure the achievement of student learning outcomes which includes dimensions of knowledge, attitudes, and skills [5]. In addition, a skills assessment is an assessment related to the skill competency of students in following the learning process, through performance assessments using practice tests, projects, and portfolios [6]. Things that need to be considered when conducting an assessment are: The instrument must be directed to measure the achievement of competence, the instrument must use the criteria reference, which is based on what students can do after going through several processes of learning, and not determine a student's position towards the group, the planned system is an ongoing system, the results of the assessment are analyzed to determine the follow-up, and the assessment system must be adapted to the learning experience [7].

Low creative thinking skills make students have difficulty in solving problems [8]. Creative thinking skills are thinking skills to generate new ideas, useful ideas, and alternative ideas that can be used to solve problems [9][10]. Creative thinking skill is not rare talents that only certain people have, but it is a skill that can be trained and developed [11]. Another opinion explained that creative thinking skill is a skill to think about many possibilities, use a variety of ways, use different points of view, think of something new, and guide us in producing and choosing alternatives [12]. Besides, creative is thinking and doing something to produce new ways or results from something that is already owned [13]. On this basis, developing creative thinking skills in students is not impossible yet it is very rational [9]. In order to create students' creative thinking abilities, innovation in learning is needed that allows students to work together with classmates as well as develop their creative skills.

Innovative learning that is relevant to the involvement and active role of students in developing creative skills is a student-centered learning model, including project-based learning. Project-based learning is a learning model that uses problems as a first step in gathering and integrating new knowledge based on experiences in real activities. Projectbased learning can provide students with a deeper understanding in terms of theoretical and practical analysis so that students are trained to be able to find concepts that are studied in a holistic, meaningful, authentic, and active manner as desired in the 2013 curriculum. Therefore, it is necessary to develop an instrument for assessing creative thinking skills based on a project, so that the instrument used is suitable for measuring creative thinking skills [14]. 
Based on the results of observations made at MAN 1 Metro on 3 physics teachers in March 2019, it was found that $70 \%$ of teachers did not conduct assessments objectively to measure student cognitive. This happens because the teacher has not made a comprehensive cognitive assessment when students do practicum activities. Teachers prefer to use written tests, while measuring students' creative thinking skills during practicum has never been done. Therefore, physics subject teachers must conduct assessments objectively to measure all aspects so that the assessment is not subjective.

Teachers who conduct subjective assessments are teachers who have not maximized the assessment system for all aspects of student competence. In terms of assessment, it was found that $20 \%$ of teachers had used performance assessments to assess student learning outcomes. However, from the results of observations that have been made, the assessment instrument is only to measure cognitive aspects in general and there are no instruments used to measure aspects of students' creative thinking skills..

From the results of the observations that have been described above, there are several gaps where no solutions were found to overcome these problems, especially those related to the objectivity and appropriateness of students' creative thinking skills instruments. It seems that no physics teacher has ever made an instrument in accordance with the 2013 curriculum to assess students' creative thinking skills. This is because the physics teachers of MAN 1 Metro City find it difficult to make instruments for students 'creative thinking skills that are in accordance with the 2013 curriculum. The results of the student questionnaire analysis at MAN 1 Metro show that $100 \%$ of class XII students agree that an instrument for assessing students' creative thinking skills is developed. In addition, $100 \%$ of students also agree that the teacher applies the instrument to assess students' creative thinking skills in the learning process in the classroom.

To identify students' creative thinking skills, appropriate instruments must be used. Therefore, what the teacher must do is compile and implement appropriate assessment instruments during physics learning. With active learning in class, students will be involved in activities that can train psychomotor aspects. So that students can have the ability to think creatively, teachers must make it a habit to practice this ability by using the right strategies in the learning process, one of which is student-centered learning. A project-based learning model is considered capable of unleashing the creative potential of students in the learning process.

Project-based learning is an ideal learning model to meet 21 st-century educational goals because it involves the $4 \mathrm{C}$ principles of critical thinking, communication, collaboration, and creativity (critical thinking, communication, collaboration, and creativity). The results of research on project-based learning indicate that such learning provides students with an advantage in factual learning compared to learning in more traditional classrooms [15]. Project-based learning is tremendous for improving students' creative thinking skills [16]. Project-based learning is a learning approach that involves students in solving problems and providing meaningful assignments for students, encouraging students to work independently in building learning, and in the end, producing real work [17]. The advantages of project-based learning are: increasing students' learning motivation, fostering excitement in students because learning in projects is more fun than other curriculum components, increasing problem-solving skills, increasing collaboration skills, making students aware of the importance of group work in projects that require students to develop and practice communication skills, improve resource management skills, provide learners with experience learning and practice in organizing projects, and train students to be able to manage time allocations and other tools such as equipment to complete assignments [18]. In addition, the project-based learning model has a significant 
effect on creative thinking skills and student learning outcomes. This result is then supported by the n-Gain result which shows the moderate category. In addition, the increase in scores on the affective and psychomotor aspects of students was in the very good category [19].

The development of instruments is very important to measure certain competencies or abilities for activities that have been carried out in learning activities [20]. Assessment is the process of collecting various data that can provide an overview of the learning development of students [21]. Another opinion suggests that assessment is the process of concluding and interpreting facts and making basic professional judgments to make policies based on a set of information [22]. In addition, assessment is part of learning activities carried out to determine the achievement of student competencies which include knowledge, skills, and attitudes [23].

Many researches related to instrument development have been carried out, including Describing the appropriateness of student performance assessment instruments in polar and non-polar compound practicums in terms of construction validity, content, and language. This research is development research that refers to the 4-D model (four-D Models) [24]. Research to analyze instruments in schools, develop instruments to measure higher order thinking skills, and test the effectiveness and practicality of the instruments. The instrument was declared valid, reliable, and practical and had a positive effect on cognitive learning outcomes [25]. An instrument designed for the assessment of student performance in a PBL classroom tutorial setting, when used wisely with the provided criteria guidelines, is feasible, and sufficiently reliable [26]. So far, there has been no research that discusses creative thinking skills assessment instruments in project-based physics learning.

Based on several problem findings and some previous research results, the researcher developed an instrument for creative thinking skills in project-based physics learning. This research is important in order to create an instrument to measure creative thinking skills in problem-based physics lessons, which is valid for use based on expert judgment.

\section{METHOD}

The research method used is research and development (Research and Development). The development in question is the making of instruments for creative thinking skills at the senior high school level. It is hoped that the resulting instrument can be used as an assessment of creative thinking skills and can objectively assess learning outcomes through the application of project-based learning.

This research and development design is based on the adaptation of the development model steps from Borg and Gall. The steps are: (1) Finding the potential and problems; (2) data collection; (3) product design; (4) design validation; (5) design revision; (6) product testing; (7) product revision; (8) trial use [27]. The development steps taken in this study are described in Figure 1 


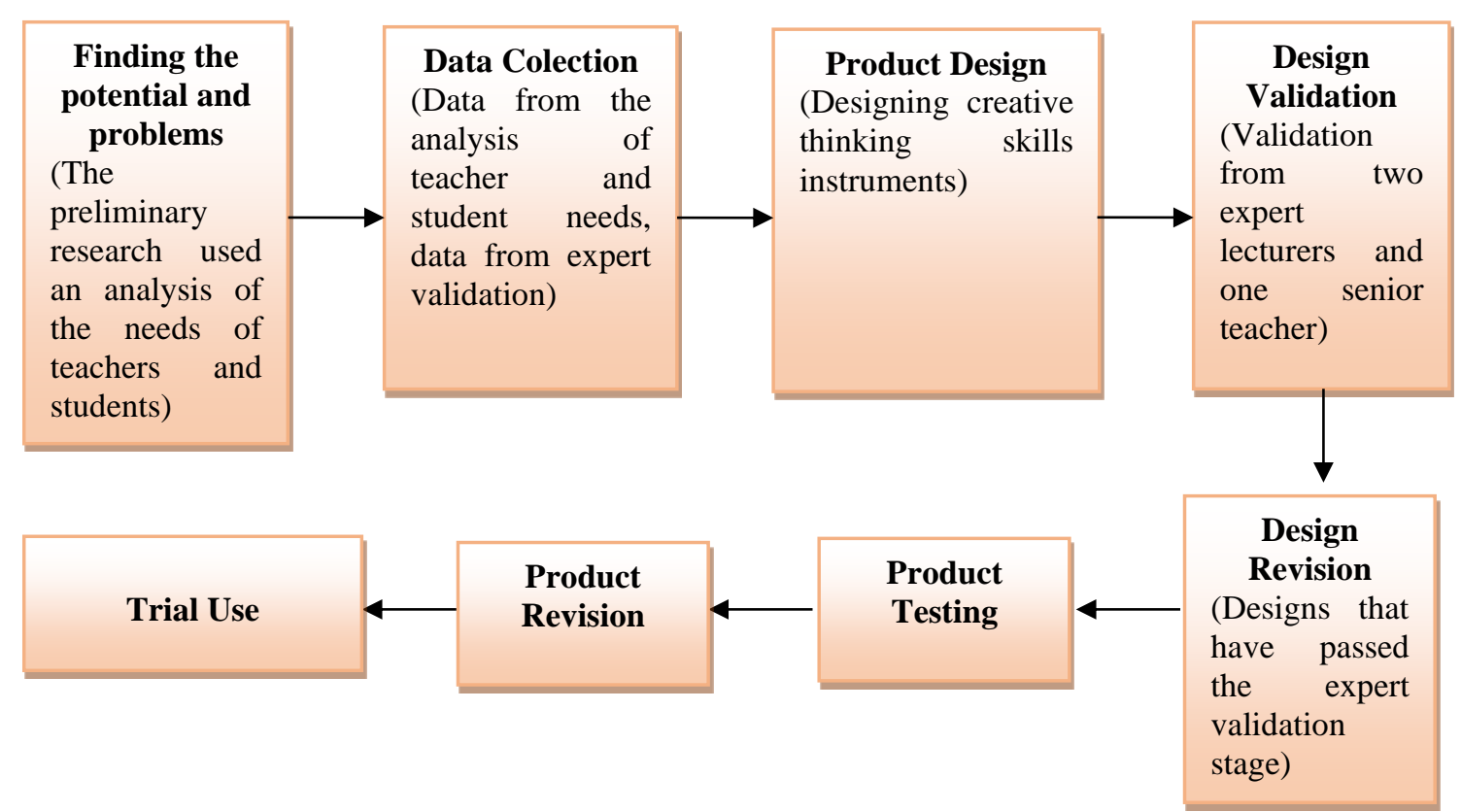

Figure 1. The Development Steps

The sampling technique was purposive sampling, the schools were selected based on the researcher's consideration of the quality of the school, they were schools that had accreditation ranging from the highest to the lowest. The instrument used in this study was a needs analysis questionnaire, a construction suitability test questionnaire, substance, and language as well as a questionnaire to test the validity.

\section{RESULTS AND DISCUSSION}

Based on the results of the research and development, the following are the details of the research results related to the development of an instrument for assessing students' creative thinking skills in project-based physics learning.

\subsection{Finding the Potential and Problems}

Based on the results of preliminary research conducted at MAN 1 Metro on 3 physics subject teachers in March 2019, it was found that 70\% of teachers did not conduct assessments objectively to measure student cognitive. This happens because the teacher has not made a comprehensive cognitive assessment when students do practicum activities. Teachers prefer to use written tests. The results of the student questionnaire analysis at MAN 1 Metro showed that $100 \%$ of class XII students agreed to the development of students' creative thinking skills instruments. In addition, $100 \%$ of students agree that the teacher applies the instrument to assess students' creative thinking skills in the learning process in the classroom.

\subsection{Data Collection}

The data obtained in this study are data from preliminary research through interviews and questionnaires, and data from the validation of instrument products by experts in the form of questionnaires. Preliminary research data through interviews and filling out a questionnaire by three physics teachers and data from student questionnaire analysis. Instrument product validation data through a questionnaire was carried out by two expert lecturers and one senior teacher. 


\subsection{Product Design}

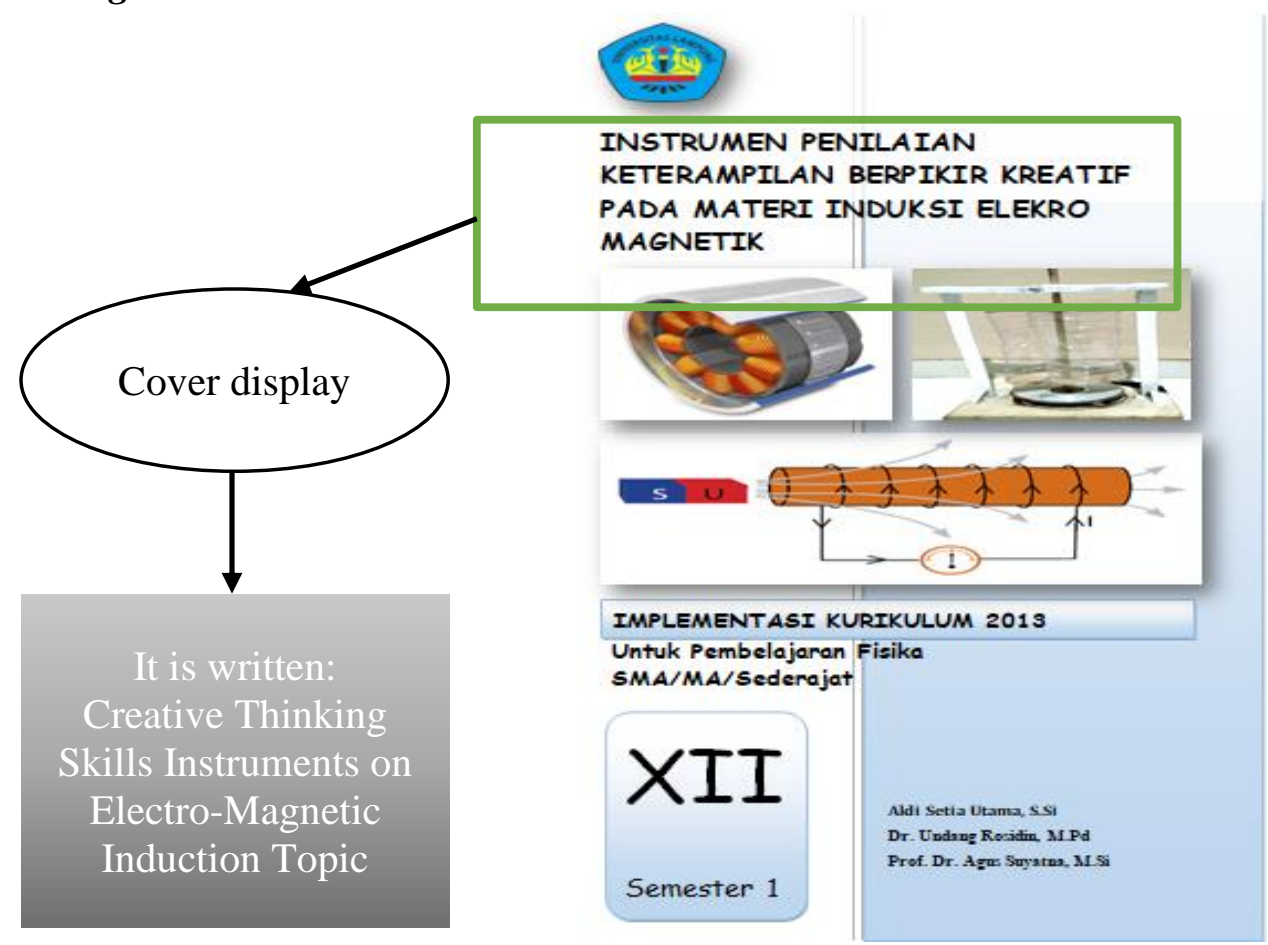

Figure 2. Cover

The instrument design contains core competencies, basic competencies, and indicators of creative thinking skills and PjBL steps. As shown in Figure 3.

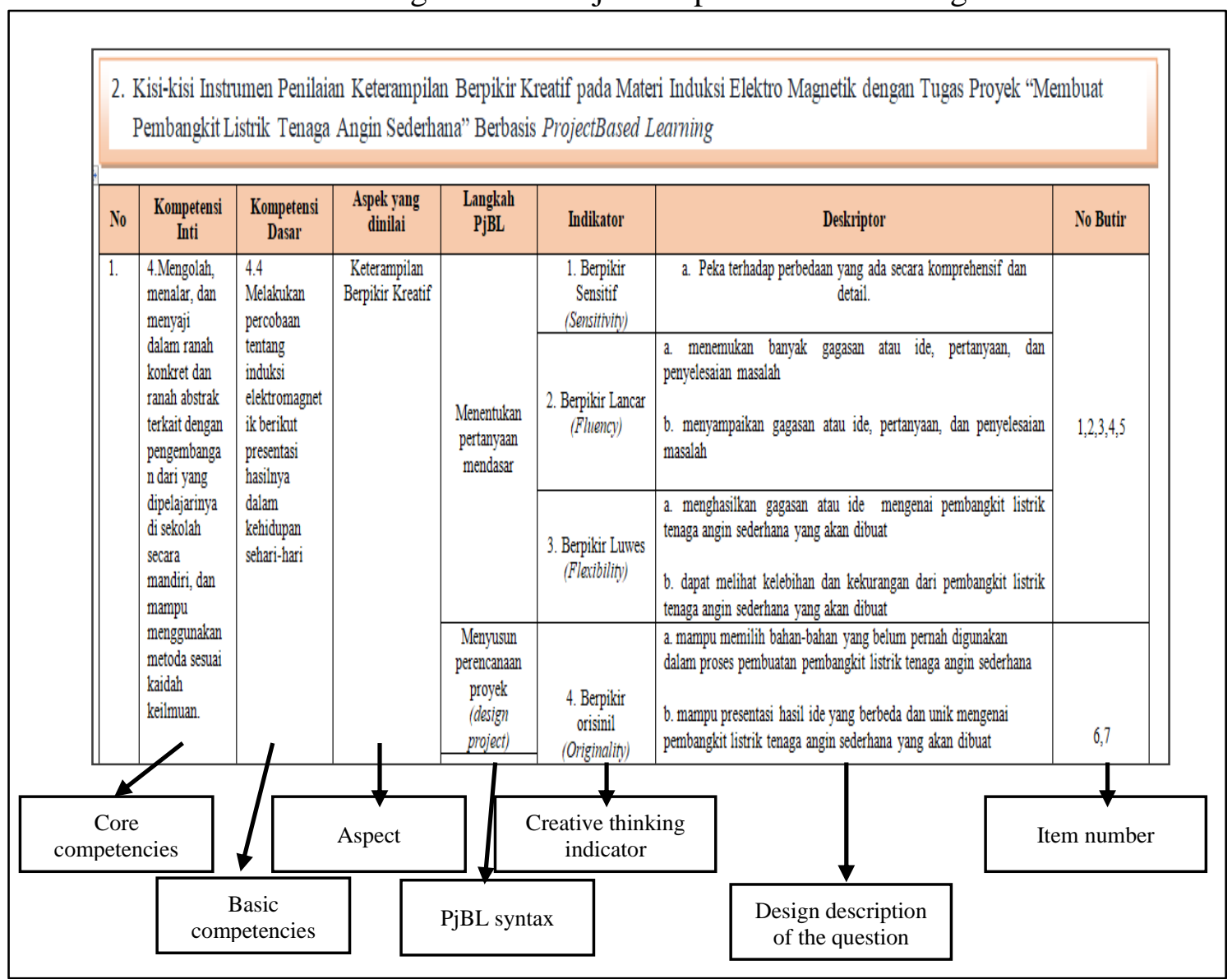

Figure 3. Instrument Design 
The instrument rubric contains the answers according to the indicators of creative thinking skills along with the scoring guidelines. It can be seen in Figure 4.

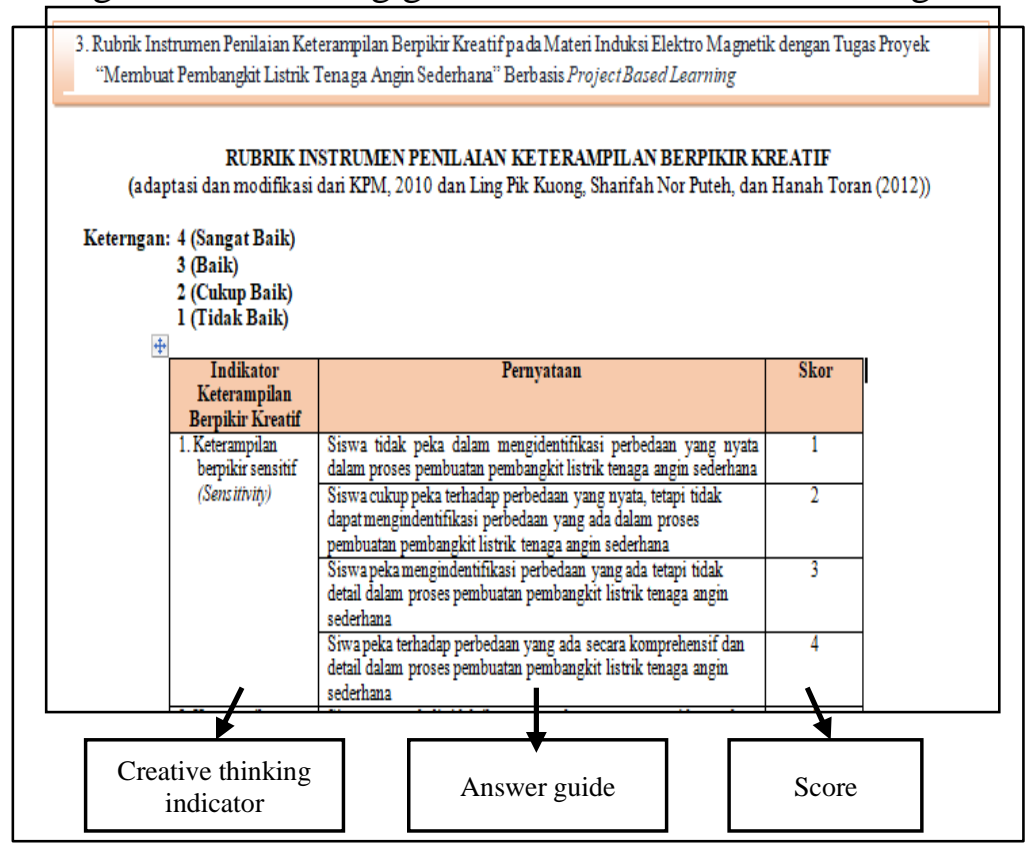

Figure 4. Assessment Rubric

The teacher used the assessment sheet to record the scores of students' creative thinking skills in the learning process. It is shown in Figure 5.

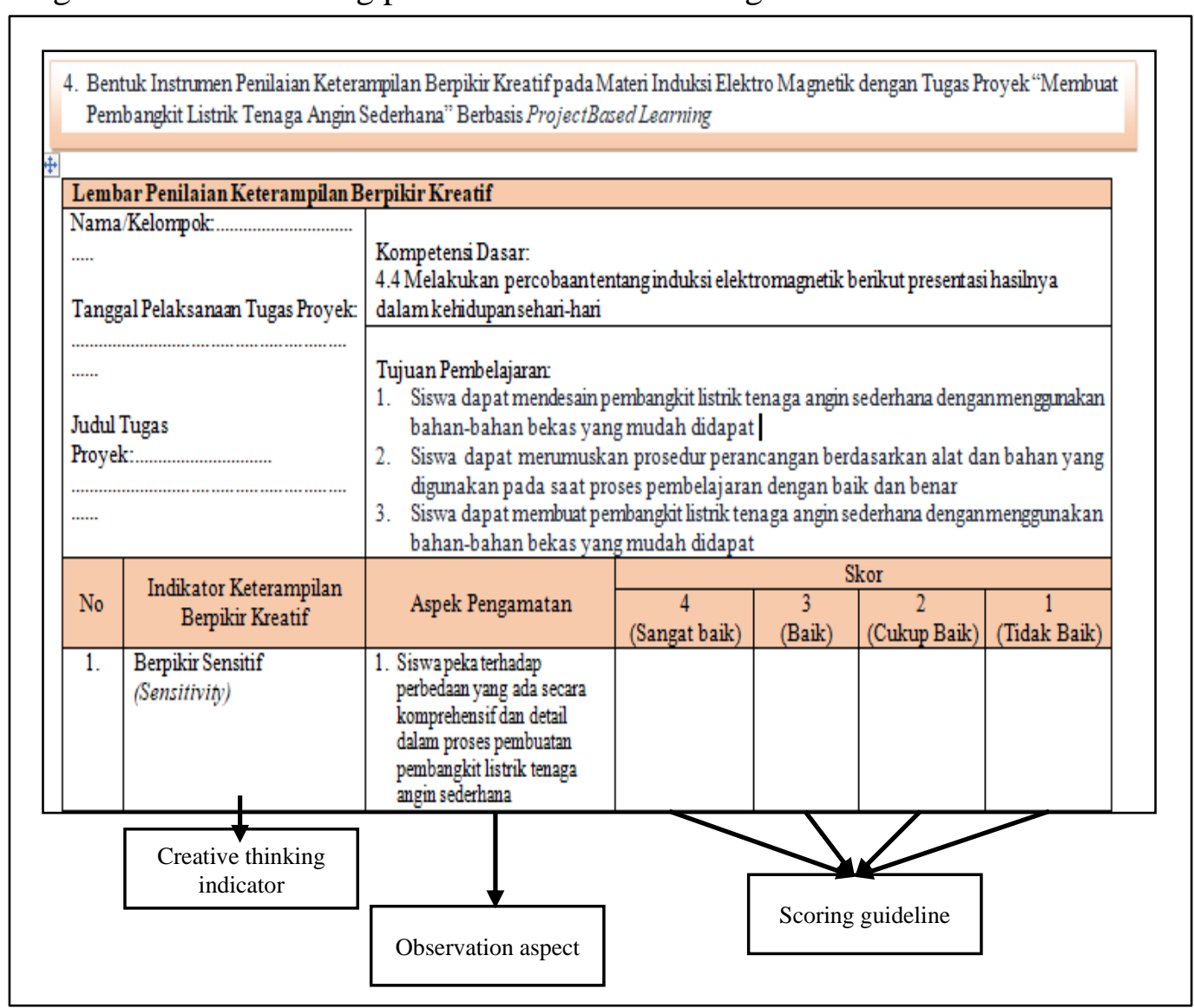

Figure 5. Assessment Sheets 


\subsection{Instrument Product Validation Results}

Before being tested on students, the instrument was validated by substance and design experts to determine the feasibility of the product development in this study. From the results of the expert's assessment, then the calculation of the validity level of the instrument is carried out as described in Table 1.

Table 1. Expert Validation Test Results

\begin{tabular}{ccccccc}
\hline \multirow{2}{*}{ No } & \multirow{2}{*}{ Aspect } & \multicolumn{3}{c}{ Validation Score } & \multirow{2}{*}{ Average } & \multirow{2}{*}{ Criteria } \\
\cline { 3 - 5 } & & Validator 1 & Validator 2 & Validator 3 & & \\
\hline 1 & Construction & $83 \%$ & $86 \%$ & $81 \%$ & $83 \%$ & Very Valid \\
2 & Substance & $80 \%$ & $86 \%$ & $91 \%$ & $86 \%$ & Very Valid \\
3 & language/culture & $92 \%$ & $92 \%$ & $75 \%$ & $86 \%$ & Very Valid \\
\hline
\end{tabular}

The validation test questionnaire contains 9 points of construction aspects. The total average score of the three validators regarding the construction aspects of the instrument is $83 \%$ which means very valid. The validation test questionnaire contains 11 points of aspects regarding the substance. The total average score of the three validators regarding the substance aspect of the instrument is $86 \%$ which means it is very valid. The validation test questionnaire contains 3 points of language/culture aspects. The total average score of the three validators regarding the language/culture aspects of this instrument is $86 \%$ which means very valid. The diagram of the results of the instrument feasibility test with the aspects of construction, substance, and language/culture can be seen in Figure 6 .

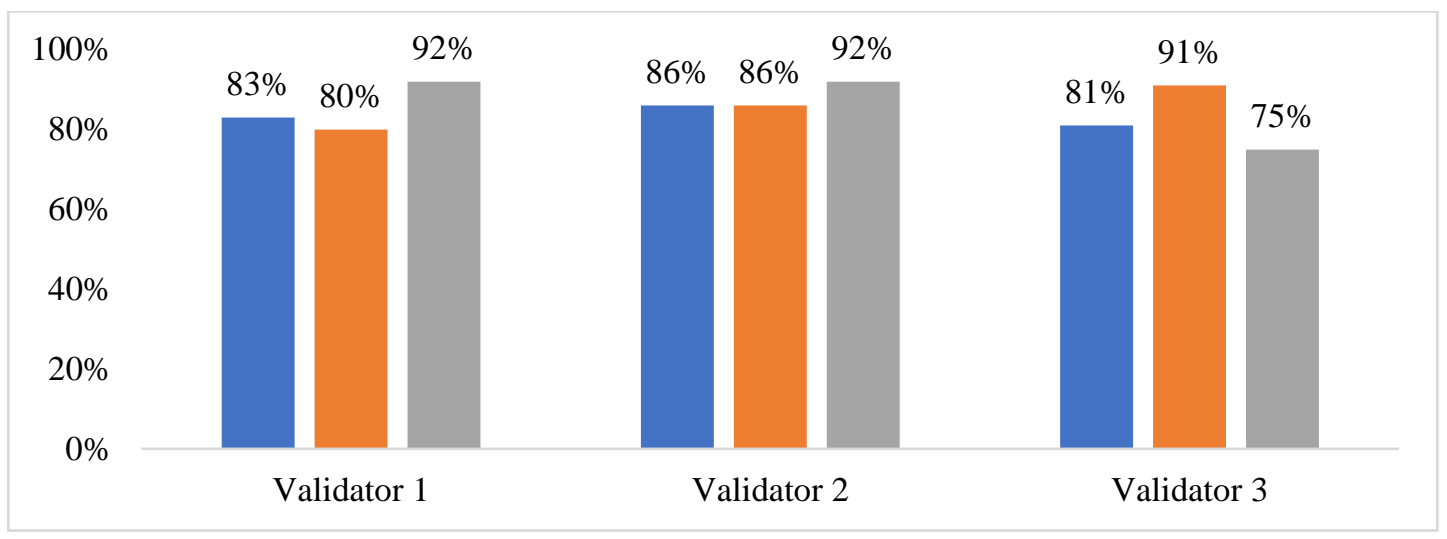

Figure 6. Graph of Expert Validation Results

The assessment instrument developed has been validated in terms of construction, substance, and language by three validators. The total average score of the validators regarding the fulfillment of the construction aspects of the developed instrument is $83 \%$, so the eligibility of the instrument is very valid, this is in line with the claim of Wusqo et al, that the validity of the design of the assessment product by experts is judged from several wrong aspects. the only thing is the construction aspect [28]. The requirements for a good instrument are valid in content aspect and constructively valid [29]. Accordingly, it follows that it may be concluded that the instrument could be passed on to be produced with minor improvements to the statement items section. The researcher improved the scale used in the scoring guidelines and the final assessment guide, rubrics, writing system, and shape format as suggested. Overall, the assessment tool for creative thinking skills is feasible in terms of construction.

The total average score of the three validators regarding the substance aspect of the instrument is $86 \%$ which means very valid. The instrument is said to be suitable for use, it can be seen in terms of content, construction, and language. The validity of a statement 
can also be seen from the suitability between the statement and the indicator [30]. This shows that the instrument of creative thinking skills is feasible in terms of the substance of the instrument and can be continued to be produced with minor improvements.

The total average score of the three validators regarding the fulfillment of language aspects is $86 \%$ which means very valid. This means that the assessment tool for creative thinking skills as a result of the development is feasible in terms of language. This is based on the reason that this assessment tool has met the criteria for language aspects, such as communicative statement language, and is in accordance with the respondent's education level, the statement used standard Indonesian, and the language used is easy to understand. The three validators did not provide specific suggestions for improvement regarding language/culture aspects.

The result of the percentage score mean instrument eligibility is $85 \%$ which means very valid. The assessment is based on the reason that the instrument has met the feasibility in terms of construction, substance, and language / culture. This reason is in line with the provisions contained in the Copy of the Attachment to Regulation of the Ministry of Education and Culture No. 66 of 2013 concerning Educational Assessment Standards, which states that the assessment instrument must meet the requirements of the substance that represents competence, construction that meets technical requirements in accordance with the form of the instrument used, and uses good and correct and communicative language according to the level of development of students. [30].

\section{CONCLUSION}

Based on the results of research and the results of the assessment by the three validators which include aspects of construction, substance, and language. The average score of the validation results for the construction aspect is $83 \%$ with very valid criteria. The average score of the validation results on the substance aspect is $86 \%$ with very valid criteria, while for the language/culture aspect is $85 \%$ also with very valid criteria. It can be concluded that the instrument of creative thinking skills has met the requirements with very decent quality and very good for use in school learning to help teachers to assess students' creative thinking skills. Based on this research, the following are suggested: conducting trials in several schools to obtain maximum validity and reliability results, developing other skills assessment instruments, and continuing development to the desimination stage.

\section{REFERENCES}

[1] U. Rosidin, Evaluasi dan Asesmen Pembelajaran. Bandar Lampung: Media Akademi, 2017.

[2] Permendikbud, Permendikbud Nomor 104 Tahun 2014 tentang Penilaian Hasil Belajar. Jakarta: Kemendikbud, 2014.

[3] A. dan A. H. Jihad, Evaluasi Pembelajaran. Yogyakarta: Multi Pressindo, 2012.

[4] L. Penelitian, D. A. N. Pengabdian, and K. Masyarakat, Universitas Negeri Semarang, vol. 4, no. 024. 2014.

[5] Permendikbud, Permendikbud Nomor 66 tahun 2013 tentang Standar Penilaian Pendidikan. Jakarta: Kemendikbud, 2013.

[6] Fadlillah, Implementasi Kurikulum 2013 dalam Pembelajaran SD/MI,SMP/MTs \& SMA/MA. Yogyakarta: Ar-Ruzz Media, 2014.

[7] Trianto, Mendesain Model Pembelajaran Inovatif - Progresif. Konsep Landasan dan Implementasi pada Kurikulum Tingkat Satuan Pendidikan (KTSP). Jakarta: Kencana., 2009. 
[8] S. Amtiningsih, S. Dwiastuti, and D. Puspita Sari, "Peningkatan Kemampuan Berpikir Kreatif melalui Penerapan Guided Inquiry dipadu Brainstorming pada Materi Pencemaran Air Improving Creative Thinking Ability through Guided Inquiry Combined Brainstorming Application in Material of Water Pollution," Proceeding Biol. Educ. Conf., vol. 13, no. 1, pp. 868-872, 2016.

[9] Y. Abidin, "Revitalisasi Penilaian Pembelajaran dalam Konteks Pendidikan Multiliterasi Abad Ke-21," Bandung: PT. Refika Aditama, 2016.

[10] R. L. DeeHan, "Teaching Creative Science Thinking," Sci. Educ. J., vol. 14991500, p. 334, 2011.

[11] A. Nggermanto, Kecerdasan Quantum: Melejitkan IQ, EQ, dan SQ. Bandung: Penerbit Nuansa Cendekia, 2015.

[12] A. Busyairi, "Analisis Didaktik untuk Meningkatkan Keterampilan Berpikir Kreatif dalam Pemecahan Masalah Siswa SMA Pada Pokok Bahasan Listrik Dinamis," J. Pros. Simp. Nas. Inov. dan Pembelajaran Sain Univ. Pendidik. Indones., vol. Volume 3 N, pp. 593 - 596, 2015.

[13] R. Listiyarti, Pendidikan Karakter dalam Metode Aktif, Inovatif dan Kreatif. Jakarta: Erlangga, 2012.

[14] Irmayati, Pengembangan Instrumen Penilaian Keterampilan Kreatif dalam Pembelajaran Tematik Terpadu dengan Pendekatan Project Based Learning. Lampung: Universitas Lampung, 2017.

[15] S. Zubaidah, Keterampilan Abad ke-21: Keterampilan yang diajarkan Melalui Pembelajaran Universitas Negeri Malang. 2016.

[16] N. M. D. P. Navies Luthvitasari and S. Linuwih, "Implementasi Pembelajaran Berbasis Proyek Pada Keterampilan Berpikir Dan Kemahiran Generik Sains," Innov. J. Curric. Educ. Technol., vol. 2, no. 1, 2013.

[17] K. Komalasari, Pembelajaran Kontekstual, Konsep dan Aplikasi. Bandung: Refika Aditama, 2010.

[18] Ngalimun, Strategi dan Model Pembelajaran. Yogyakarta: Aswaja Pressindo, 2013.

[19] F. Wahida, N. Rahman, and T. Gonggo, "Pengaruh Model Pembelajaran Berbasis Proyek Terhadap Keterampilan Berpikir Kreatif Dan Hasil Belajar Siswa Kelas X SMA Negeri 1 Parigi," J. Sains dan Teknol. Tadulako, vol. 4, pp. 36-43, 2015.

[20] Hosnan, Pendekatan Saintifik dan Kontekstual dalam Pembelajaran Abad 21. Bogor: Ghalla Indonesia, 2014.

[21] Kunandar, Penilaian Autentik. Jakarta: Raja Grafindo Persada, 2013.

[22] R. Abdullah Sani, Pembelajaran Saintifik untuk Implementasi Kurikulum 2013. Jakarta: Bumi Aksara, 2014.

[23] R. Sunarti \& Selly, Penilaian dalam Kurikulum 2013-Membantu Guru dan Calon Guru Mengetahui Langkah-Langkah Penilaian Pembelajaran. Yogyakarta: Andi Offset, 2014.

[24] F. K. Ningtyas and R. Agustini, "Pengembangan Instrumen Penilaian Kinerja Siswa untuk Mengakses Keterampilan Proses Dalam Praktikum Senyawa Polar Dan Non Polar Kelas X SMA," UNESA J. Chem. Educ., vol. 3, no. 2252-9454, pp. 169-175, 2014.

[25] Lissa, "Pengembangan Instrumen Penilaian Keterampilan Berpikir Tingkat Tinggi Materi Sistem Respirasi dan Ekskresi.," J. Pascasarj. Univ. Negeri Semarang, vol. 41, pp. 27-32, 2012.

[26] N.-H. T. Si-Mui Sim, Nor Mohd Adnan Azila, Lay-Hoong Lian, Christina PL Tan, A Simple Instrument for the Assessment of Student Performance in Problem-based Learning Tutorials. Annals Academy of Medicine35, 2006. 
[27] Sugiyono, Metode Penelitian Kuantitatif, Kualitatif, dan R\&D. Bandung: Alfabeta, 2014.

[28] I. U. Wusqo, M. Taufiq, and R. Handayani, "Pengembangan Asesmen Alternatif Praktikum Kimia Dasar Ii Melalui Chemistry Fair Project (Cfp) Berbasis Konservasi Dengan Memanfaatkan Daily Chemical," J. Penelit. Pendidik., vol. 33, no. 2, pp. 145-154, 2016, doi: 10.15294/jpp.v33i2.9096.

[29] E. Wijayanti and M. Mundilarto, "Pengembangan Instrumen Asesmen Diri Dan Teman Sejawat Kompetensi Bidang Studi Pada Mahasiswa," J. Penelit. dan Eval. Pendidik., vol. 19, no. 2, pp. 129-144, 2015, doi: 10.21831/pep.v19i2.5572.

[30] S. R. Hidayat et al., "Pengembangan Instrumen Tes Keterampilan Pemecahan Masalah pada Materi Getaran, Gelombang, dan Bunyi," J. Penelit. Pengemb. Pendidik. Fis., vol. 3, no. 2, pp. 157-166, 2017, doi: 10.21009/1.03206. 